\title{
The Role of Local Institutions To the Embodiment of Reconciliation in Singkawang
}

\author{
Hasan Almuthahar ${ }^{1}$, Syarifah Ema Rahmaniah ${ }^{2}$, Elyta Elyta ${ }^{3}$ \\ \{hasanalmutahar65@gmail.com¹,ema_rahmaniah@yahoo.com², elyta.elyta79@gmail.com ${ }^{3}$ \} \\ ${ }^{1,2,3}$ Faculty of Social Science and Politics, UniversitasTanjungpura, Jl. Prof. Dr. H. Hadari \\ Nawawi, Bansir Laut, Kota Pontianak, Kalimantan Barat 78115, Indonesia
}

\begin{abstract}
This article aims to explore the issue which had sparked the conflicts that occurred in many parts of Singkawang between the year of 2010 to 2013; five of which took place in the South of Singkawang, four cases in the West and Downtown Singkawang, another two happened in the Central and East of Singkawang. Notably, it is important to say that due to its low effects - and being recognized as non-communal conflicts, we agree that Singkawang constitutes a territory with a less escalation potential conflict located in West Kalimantan. The paper also provide explanations to the constructive role of the local institutions - such as The Institution of Dayak Tradition (IDT), The Assembly of Malay Tradition and Culture (AMTC) and The Assembly of Chinese Tradition (ACT) - in stimulating togetherness and mutual cooperation. Integrated with the local government institutions formed by the board of Welfare Development and Public Agencies, these traditional institutions enact several institutions such as the Apparatus of National Assimilation (ANA), the Apparatus of Initial Vigilance (AIV), the Apparatus of Communication of Religious Society (CRS) and the Communication of Regional Intelligent (CRI) for the effort of reconciliation. Basically these organizations and agencies work in close knit to discover prevent and finally arrive at a resolution for any form of conflict that may arise and hence reviving the role of religion and the traditional institutions.
\end{abstract}

Keywords: Conflict, Local Institutions, Reconciliation.

\section{Introduction}

The scope of social conflict found in Kalimantan does not merely associated with identity and religion issues; rather a more extensive one known as the factor of "supra-local force" such as the one that had attacked the country of Indonesia around 1997 to 1998 - the monetary economic crisis. It is recommended to engage a gradually, wary, specific locality efforts in accord with conflict prescription without subjecting the macro setting attached on the occurrence of social conflict.Galtung as cited in Syafruddin states that there are three core elements of conflict, a) the contradictory interest, b) negative behavior in the form of perception as well as stereotype flourished on both sides of the parties involved, and c) the embodied violence and impendence. The set of proposition emerges within relationship established between the distinct parties, will lead to an exposed conflict. As the data raised from the work points out, we concluded that there are three main reasons that had caused social conflict in Singkawang [1].

The first issue is related to the conflict of interest generated by a perceived rivalry interest or those which are obviously stand on the opposite side. This issue of interest comes up to be a potential conflict when a party on one side is being deprived from accomplishing their desired 
goal. A manipulative rivalry between two or more parties also characterizes this type of conflict of interest. The cause that might encourage this interest-based conflict is the discourse related to some fundamental such as economic and political power; and principles and psychological issues. For instance, in the year 2012 a political conflict occurred among the coalition political parties during a mayor electoral process.

The conflict of value triggered by the difference of the social system beliefs; this is second issue constituting the reason for social conflict in Singkawang. Value is conceived as belief which sets apart good from bad, right or wrong, fair or unfair; and functioned socially dependent on one's culture. The diversity of value, however, should not act as a factor contributing to the conflict; rather the people are idealized to be able to contiguously live in harmony. The conflict of value emerges as the result of coercion of a particular value system onto the others and a claim of exclusiveness of a certain system over a rival system.

The psychology of social relation completed the main reasons contributing to social conflict in Singkawang. It has been recognized that social interaction between individuals, community, and nation occupies the realm of society life; however, arguably there is an inclination of distrust within the people - in the process of interacting with each other resulting in negative perception toward others. This bias of perception, called as stereotype, plays the embryo of prejudice espoused with discrimination over a society and may conclude in violence. Those prejudices come up as the product of bias-perception, or say 'a stereotyped', as unreasonable judgment which lead to a misstep action without an existence of preceding delicate appraisal. Thus, besides the diversion of sight to what is said as reality, another impact - the tendency of generalization - delivers negative impact within community presumed as marginal - both in the significance, quantity or social status.

In 2003, the building of a dragon sculpture downtown of West Singkawang district was halted for five years and continued in 2008. The sculpture had brought uneasiness among the Muslim community because they were not invited for any discussion regarding the location of the landmark. The Islamic Defenders Front (FPI), acted as the representative of the society council in Singkawang, planned to cover the whole sculpture with white clothes orif possible, destroy it. What energizes this conflict was the presumption of the absence of ethnical esteem. FPI community suggested that the municipality, as the authority, was supposed to organize a discussion with the public on the building of the sculpture -especially related to its location. As a result with the existence of prejudices, the conflict of social relationship and psychology occurred. The issue above shows the inefficient governance practice that could lead to bloodshed. Further, the diversity of culture is not solely the reason for the conflict; political intercession also has the potential of marginalizing the needs of a particular ethnic or social community.

This article takes into account on regard to the following inquiries a) how do the local agencies, the culture and religious institutions in Singkawang consent to the construction of reconciliation and b) how does the local wisdom promote a sustainable reconciliation to the people living in Singkawang. To answer these questions, a set of topography is necessary to draw a vivid picture on the existing basic issues as an attempt to assignaccurate wisdoms and programs to support the resolution of the social issues in this territory. Theory of local wisdom as well as the role of local institution functioned well in this writing, as means to the construction of reconciliation.

Work on the local wisdom, it is assumed that the work strengthens the idea of the local institution role and its importance as an integral part of local wisdom and addressed the construction of reconciliation against the faded trust that the public feel towards the governmental agencies [2]. Then, he was signifying the local wisdom as an all human attempts 
in maximizing the merits of their common sense (cognition) to perform an accurate action and manner towards particular things, objects, or facts occurred in a certain space. This argument is, as it is like-minded, explicitly reinforced by Haba, the local wisdom functions as stimulant to the construction of integrity as well as esteem among the people. He says further that the wisdom constitutes public mechanism -arises from public recognition- works on the reduction and prevention against the subverting communal solidarity in an integrated society [3].

\section{Perspective and the Strategy of Conflict}

Two theoretical perspectives to supply the inquiry into the violence that flourished in the embodied conflict [4]. The first perspective is, he believes, explicating the violence as an inevitably part of mode the conflict relation creates in a susceptible society like those belong to Indonesia. There are factors that open the possibility of susceptible society, the first of which is called as the social cleavages, which works on the partition of society into heterogeneous community-identity - the practice is visibly captured in Pontianak, within which three large communities emerged from three large ethnics, namely Malay, Dayak and Chinese. The following factor, as previously thought, is the emerging competition amongst society toward an attempt to the control of restricted sources which is supposed to be well-addressed by the poor institutionalization works on the conflict governance. The absence of conflict governance, as the potential institution toward the reconciliation, is ascribed as an open gate to the violence within each conflict of interest. The institutionalization of conflict governance is thus related to the agencies of municipality such as the Indonesian National Army (INA), the constabulary, the city social service and the city political welfare development. However, the institution that acts as the mediator here belongs to a local one; say the culture and religion institution, which is believed to open the trust and space attached by society.

In germane with this issue, categorizes five strategies of conflict, namely the strategy of contending, withdrawing, yielding, compromising, and problem solving- on behalf of the group of interest [5].The first strategy is marked with the constructed denial toward the goals and desires pursued by different parties; the whole attempt to the resolution of conflict, therefore, has to provide the benefits to the goal the conflict aspires. An effort sought by Islamic Defenders Front (FPI) which was the refusal of dragon sculpture building is an instance of embodied form of contending conflict which animates the visible practice of violence and communication followed by hard conditions such as tension built on relations, threat and mutually negating. On the contrary, the strategy of withdrawing allows the possibility of one or both conflicted parties to withdraw themselves from the reciprocal situation or, for the best, repealing their claims on each other. As a result, the conflict relation will cease to exist while resolution will not emerge at all.

This type of strategy suits those who realize an intimidation posed toward the existence as well as self-safety -particularly related to resources salvation involving properties, lands, families and even the most valuable belongings, their own lives. What next is the yielding strategy of conflict in which a decision is also a resolution that wholly adhered to the opposing party; as such, an instance occurred in Singkawang, a dispute taking place between the land owner and a plantation company which ended in the owner surrendering their land without any objection. The last strategy of conflict, recognized as compromising, is marked by the compromise flourished between both conflicted parties thus, in the end, resulted in a compliance goals that each is pursuing. 


\section{Method}

In accordance with the topography of conflicted-prone territory, however, there are four pillars to satisfy; a) identification to the escalation and de-escalation of the embodied conflict; b) analysis to factors energizing conflicts whether it is a structurally-based conflict, the acceleration conflict or trigger-based conflict; c) organization of actors including securitization, functional, and prone circle; and d) the collaboration constructed amongst stakeholders. Built upon the new paradigm, for data excavating through topography, we use qualitative method on the analysis with four techniques as follows:

- Desk Research. This is conducted as a preliminary process of the research by collecting prior data,analyze the supporting data and documents which are in germane with topography practice.

- Focus Group Discussion. To obtain data from each stratum of society living in Singkawang, all the people directly involved in the social conflict and those who acted as the agents of reconciliation.

- One to One in-depth interview, a technique engaged to obtain data from The Assembly of Malay Tradition and Culture, Institution of Dayak Tradition, the Front of Islamic Defenders' figures, Chinese Community Foundation, Political Welfare Development, Intelligence and Security of Resort Police in Singkawang.

- Observation. Refers to the collection of factual information of the real condition in the public/society.

Apart from methods above the data gathered is supplemented with documentation from the local and nationwide-published media both printed and online. This collection of data is then organized and analyzed to draw the topography of the conflicted-prone areas as well as the potential conflicted territory in Singkawang.

\section{The Conflict of Tribe, Religion, Race and Class}

This mode of conflict was demonstrated by the strong objection of the Malaysia against the building of a dragon sculpture in Singkawang; then supplemented with the issue of labeling the Malay tribe as raiders. In spite of an attempt of reconciliation, however, the visceral disappointment suffered by society still present. This is, as being captured, evidenced with the immanent ripples emerged between the tribe-nuanced fellow in several areas such as that occurred in the West and South District of Singkawang.

In the political realm, the ethical group constantly accepts more considerations, especially those which are germane to the issue of cultivating collective awareness, political involvement and representation, as well as issue of tribal and nationality, which at last, creates political identity. It is important to note that the political identity might also be categorized as political culture, which bears an insight toward the indigenous and non-indigenous politic evoked by the discourse of relations between the local inhabitant and the immigrant. To this constellation, therefore, political indigenous denotes an attempt of self-protection and defense -particularly those who are associated with the local inhabitants, who generally, conceding the immigrant. By this attempt the political indigenous tries to dominate the discourse of practical politic both in local legislative and executive sides.

The practice of reclamation conducted by the Front of Islamic Defenders Front (FPI) was after the Jumu'ah (Friday congregation prayer), dated on the 28th of May 2010. Accompanied by FPI and the alliance of non-governmental organization, the FPI moved to the location where the sculpture was being built. Riding on motorcycles and armed with loud speakers, they moved to the location and orated that the local government must discontinue the work. 
The building, as argued by the protesters, would harm religious harmony since the practice ignites discriminative issue in which the local government seems to favourone particular ethnic. The establishment, furthermore, was disputed in the notion of its location, in which, according to them, are not supposed to be in the center of the city but in a particular worship site of a certain ethnic or group. Unfortunately at that time, the local government on the opposing side did not react immediately since the fund had been passed and the project was underway.

The FPI was convinced that a dragon is the symbol of certain ethnic and thus the building of the sculpture as a public site utilizing the state's budget was regarded as a discrimination against the Muslim society -as the majority inhabitants in Singkawang. Furthermore, they insisted that the building of certain ethnical symbol was unacceptable since the local government did not accommodate symbols of other religions. The FID also suggested that the building should be conducted in the area of worship not on any public site. However, the Chinese organization as well as their supporters such as the FPM and the alliance of nongovernmental organizations, argued that the building itself would be the tourism icon representing the diverse cultural range in Singkawang. Also known as Nabo in the Dayak language, they said further, the dragon is said to be an integral part of all ethnics and many nations' legend, folktale and myth; hence, they contended that this animal was neither sacral nor chaste symbol. The action of renunciation, nonetheless, was debated by the mayor of Singkawang of that time based on the view that the building suits the goal to embody Singkawang as a city of tourism.

The symbol represented by the dragon sculpture, we believe to constitutes political hegemony, displaying which community is dominant with power -despite of its minority status in society [6]. The theory of hegemony is constructed with the notion of ideas as something significant and the lack of physical enforcement in the control of social-politic, thus as a consequence; parties which are under-domination at last willing to yield through and internalization of values and norms belong to the authority. They, either consciously or unconsciously, present an agreement toward subordination subjected to them [7].

Returning to the issue of dragon sculpture building in Singkawang on previous pages, it is clearly seen that the local government unable to accommodate the interests or desires of the groups profess thus, as an outcome, is the practice of reclamation ended in conflicts. Together with the House of Regional Representatives, the local government is highly recommended to formulate regulation related to the establishment of certain groups' symbols rather than restricted-based on certain group as the representation of power but then, what is mostly desired, their symbols finally encountering people for the entity. As captured in the argument, it is also advised that the building of symbol on public sites has to as well being the representation of all the groups. As an answer to this question, consequently, formulation to the regional regulation in account with public facility and property, the building of symbol in Singkawang -for example- should be constructed. Herewith is the diagram depicting conflict between FPI and regional government in Singkawang: 


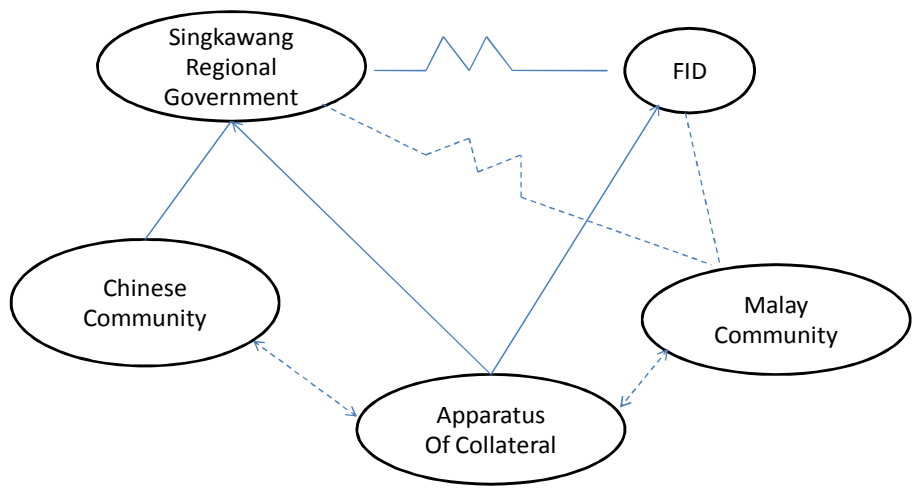

Source: [8]

\section{The Endeavor of Forming Reconciliation}

On the notion of reconciliation, there is a general consideration about a key distinction between positive and negative reconciliation. Positive reconciliation refers to the actualization of economic safety and equity from the pertaining system and the removal of existing race, ethical, religion discrimination that the social structures drives. The Non-Governmental Organization (NGO) commonly becomes the part that carries this mode of reconciliation out in an endeavor of transforming the embodied structure of violence especially in what the states practice. As such an organization called as the Indonesian Environmental Rides exists in West Kalimantan with a goal to save Borneo from the practice of destruction of the ecosystem and the inequity in plantation management.

Negative reconciliation, on the other hand, is understood in accord with the absence of direct violence in the form of war, genocide and ethnic cleansing. The conceptual insight the negative mode utters is a statement saying that reconciliation is, at any single time, possible to manifest provided that the war as well as any forms of well-organized direct violence are dissolved; hence, the practice of diplomacy, negotiation, conflict resolution and military enforcement came into effect [9].

The upcoming necessary is that the construction of multicultural awareness within the society living in Singkawang; thus, they will sincerely at last appreciating and accepting distinction flourished within the society. The practices of tolerance, collaboration, as well as interior and exterior positive stance toward the nation are recommended as the strategy for keeping the distinction to live in balance.

Multicultural awareness built through multicultural education either formal or informal acts as one of systematic undergird. This mode of education constitutes a progressive approach in an account with performing educational transformation, which is rigorous, enables lacks, failures, and discriminating practices to be discarded from the educational process. Multicultural education, as what we want to point out here, is undergirded on the notion of social and human right's equity in education. It supposes to facilitate the teaching-learning 
process which replaces the perspective of monoculture -characterized as essential, occupied with prejudices and also discriminations - toward a multicultural perspective to which differentiation, variation, tolerance, and open-minded practices are well-appreciated.

\section{Role of Religion and Traditional Institutions as the Actors of Reconciliation}

One principal domain dealing with managing conflict, which is unfortunately abandoned from the side of the elite's consideration, is an approach to the 'inward' states of the society itself. This group of social beings, frankly speaking, is armed with the capacity and the sensitivity called as "local wisdom" in maintaining the social dynamic. Empowering local wisdom as an optional resolution to conflict, as cited by Abdullah et al.; is said to be a cultural approach on the resolution of conflict or, similarly, a local wisdom based on culture and religion [10]. According to him, local wisdom refers to the variant of cultural assets that grow and develop amongst society which are well-known, presumed, and admitted as necessary elements enabling deep social cohesion within individuals.

There are at least six significance and functions of local wisdom in resolution of conflict as follows: a) as a mark of certain community's identity, b) as a cohesive aspect amongst networks of individuals, religions, and beliefs, c) as an inward awareness which does not comprising any practice of coercion, d) this local wisdom obtains the colour of entity of certain community, e) it can substitute individual and community's mindset as well as reciprocal relations then posit them after the common ground, and f) as a trigger to the process of respect and involvement also minimizing elements harming community's solidarity and integration.

The attendance of inner actor in the local wisdom as strategy germane to the option of resolution toward conflict is necessarily recommended especially to function on the ethnical and religion-nuanced conflict regardless to the debate on the admission of religion as the element of culture in public social construction. The variety of local wisdom which is evolved in the nation needs an esteem and enforcement the elites supposed to execute due to the purpose related to the success of the local wisdom itself.

It is principal to have an entity as a firm foundation in the practice of national and state of Indonesia not merely stand on 'hard devices' such as political state, territorial, and public's inclusivity entity, instead on some 'soft devices' in form of national culture existence. Such evidence mentions a thoughtful attempt by the government in order to push and revitalize the local wisdom into local capacity for peace. The wisdom, therefore, acts as a social-capital aspect answering the conflict of violence and also as an ethos in manifesting the values of solitude, equity, and welfare in Indonesia. What exemplifies the manifestation of social conflict resolution in Singkawang, is a consensus created among conflicted parties to uphold a reconciliation, achieved with the assistance of religion, traditional and society leaders and government as the facilitator.

Reconciliation, as imagined in a parable, acts as a three-partition of a tree; the root, the branch and the leaves. Endeavour conducted for an establishment of reconciliation, act as the leaves which constitute progressive mechanism toward conflict management, which is often performed in various strategies - one of which is conducted through a traditional court. The mechanism found in Singkawang germane to the conflict resolving based on ethical and cultural approach is the traditional institutions, such as the Assembly of Dayak Traditional Assembly (ADT), the Assembly of Malay Traditional and Cultural (AMTC), and the 
Assembly of Chinese Traditional Assembly (ACT), works as means to encounter capacities in socializing and internalizing the ethos of entity and collaboration within society.

To the issue that arose between FPI and regional government in Singkawang, the former plays its role as an appropriate mediator associating with the process of reconciliation. The cooperation, lives in synergy, created between society and government -who share commitment through the Welfare Development and Public Aegis- constructively plays roles in the embodiment of reconciliation among which is the establishment of institution associated with peace-custodian's notion such as the Apparatus of National Assimilation (ANA), Apparatus of Society Initial Vigilance (ASIV), Apparatus of Communication on Religious Society (ACRS), and the Communication of Regional Intelligent (CRI). This variant of traditional institutions prove the local wisdom which is naturally generated and manifested within society, generally called as a bottom up practice, such as the Basic DarulArqam, the Council of Malay Tradition and Culture, the High Council of Confucianism, Indonesian Religious Leader (in Indonesia called as MUI), Nahdatul Ulama (NU), and Muhammadiyah, etc. Belongs to this variant, furthermore, are some new organizations such as the Apparatus of Malay Juveniles Communication (AMJC), the Apparatus of Dayak Juveniles Communication (ADJC), GPAnsor, and so on. Other variants of local wisdom, we desired to add are those, generated in form of the alignment between society and regional government, has been mentioned previously yet notably significant to consider such asthe Apparatus of National Assimilation (ANA), Apparatus of Society Initial Vigilance (ASIV), Apparatus of Communication on Religious Society (ACRS), the Communication of Regional Intelligent (CRI) and, last but not least, the mass media.

What follows is an outward conducted process, surmised as the branch of a tree, germane to the program and endeavor attached to the reconciliation such as rural meeting, traditional figures meeting, and the like. Paraphrased as the body part of a tree, reconciliation's systemic pillar is then said to be the root functioned as the base of achieving the practice of reconciliation or capacity in managing conflict. This performed practice works as an intention intensifying multicultural awareness; once it is achieved, people living in Singkawang will regard and appreciate the existing diversity without trying to make it homogenousor, worst, disappear. As stated in advance, the practices of tolerance, collaboration, as well as interior and exterior positive stance towards the nation are recommended as a strategy for keeping the distinction to stay in balance.

The leaders of society, religion, and culture, and figures living in West Kalimantan, so far, represent essential actors within the endeavors of reconciliation. Their enthusiasm as mediators once a conflict takes place between individuals or groups has become an instance of their involvement in the narration of reconciliation. Several attempts of mediation as well as creating good communication with those involved in the conflict has been the strategy conducted by the figures so far. Once the ethnical matters come into surface, the ethnics' leaders encounter it by performing mediation, interweaving good communication and seeking resolution, likewise when a conflict captured within the notion of tradition and culture, their leaders soon act as the mediators as well. There are evidences in form of various organizations including the social and religion board say as Indonesian Religious Leader (it is called as MUI in Indonesia), NahdatulUlama (NU) and Muhammadiyah for Muslim; The Unity of Church for Christians, and Walubifor Buddhist, to witness the significance role these figures and institutions bear.

The presence of the Indonesian National Army in Singkawang, in any case, demonstrates the foremost and significant role in perpetuating the feeling of safety amongst the public. The conduct is, necessary to say, not merely an action of discontinuation directed to the conflict 
itself, instead, the action of recuperation and prevention against the repetitive of the conflicts. Based on information gained in the interview, on the contrary, the authority covers National Army as well as the constabulary - particularly the intelligence and security board- gives more attention to the practice of discontinuation, better than recuperation and prevention, to end the conflict. The prevention and also the recuperation, unfortunately is infrequently engaged as the security forces recognized in the strategy in account with these two notions are found to be restricted.

To this fact, we argue that it is necessary to build cooperation among the related parties on behalf of conflicts controlling, for instance the interrelated network between social departments and political welfare development on each level of territories - province, regency, and town - accompanied by public organization and its figures to conduct the shared (responsibilities) actions i.e. endeavoring prevention and recuperation upon the rising conflict. Thus, for a certain party to pledge for a safety situation without the assistance of the other parties involved is unreliable; discontinuing conflict, extinguishing fires -for example, is not solely what should be done, rather a further action of prevention is required This articulates significant actions as well as strategy to detect and anticipate when a conflict might arise.

In order to achieve the desired reconciliation within the aspects of political and socialculture; economic and resources, anticipative and preventive efforts are necessary to be conducted by the entire elements concerned through strategies prevailing the apparatus of initial detection and vigilance initiated by the community of regional intelligence, the apparatus of societal initial vigilance, religious society, and of national assimilation. Local wisdom established to control social conflict resulted in a favorable situation in Singkawang, thereby, formulated in form of agreement upon reconciliation carried on by religion, tradition, and society figures which is supported by the government. Due to the embodiment of harmony within ethnics, "Batik Tidayu" as well as "Tidayu Dance" appears to be a typical precious product the society creates. These two regional belongings represent the characteristics of three large immanent ethnics - Chinese, Dayak and Malay.

\section{Conclusion}

What we want to emphasize here are the acknowledgements on the actions of the endeavor of the apparatus and government establish which is, unfortunately, focuses on the conflict resolution rather than prevention upholding the democracy conflict governance as the pillar. Constructive role by the local institutions capacitate, such as Dayak Tradition, Malay Tradition and Culture, and Chinese Tradition Assemblies - to build an ethos of partnership and mutual cooperation, is possible to socialize and internalize within the society by means of multicultural education flourishing the activities the local institutions empower, among public realm. However the effort of the local institutions working on the resolution, has not yet met its desired synergy with some variant from other social organizations and other government's agencies. It is recommendable, anyway, for the concomitant parties to create cooperation such as collaboration and engaging with each territorial level of social departments and political welfare development, public organizations and its figures in accord with the notion of prevention and recuperation after conflict. This is important for the purpose of establishing and recovering the strategic role of principles of local wisdom which will eventually plays an integral part in the process of intact construction of the nation and the Indonesian people. The strategies in account with reorganizing principles of local wisdom, therefore, constitutes nothing impossible - or said utopian - since this mode of wisdom remains a social reality 
predicated among Indonesian people and carry the potency as national strategy germane to the practice of initial vigilance and anticipation toward an advance occurrence of social conflicts.

\section{References}

[1] Johan Galtung, Studi Perdamaian: Perdamaian Dan Konflik Pembangunan Dan Peradaban.Translated by AsnawiSyafruddin.Surabaya: Pustaka Eureka, pp. 21, 1996.

[2] Joko Tri Haryanto, "Kearifan Lokal Pendukung Kerukunan Beragama Pada Komunitas Tengger Malang Jawa Timur," Balai Penelitian dan Pengembangan Agama (Jurnal Analisa), vol. 21, no. 2, Desember 2014.

[3] John Haba, Revitalisasi Kearifan Lokal: Studi Resolusi Konflik di Kalimantan Barat, Maluku, dan Poso. Jakarta: ICIPdanEuropeanCommision.

[4] Novri Susan, Negara Gagal Mengelola Konflik Demokrasi dan Tata Kelola Konflik di Indoneisa. Yogyakarta: Kopi, pp. 21-22, 2012.

[5] Pruit, G. Dean, and Hee Kim Sung, Social Conflict: Escalation, Stalemate and Settlement. (3rd Edition), pp. 4-6. New York: McGrawHill.

[6] Antonio Gramsci, Selections form the Prison Notebook. Edited and translated by Quince Hoore \& Goffrey Nowell Smith. London: Lawrence and Wishart, 1971.

[7] S. Hobden \& R. W. Jones. The Globalization of World Politics: An Introduction to International Relations. Dlm. S. Smith \& J. Baylis (pnyt). Marxist Theories of International Relations. Oxford: Oxford University Press, 2001, Ed. 2, pp. 200-223.

[8] Syarifah Ema Rahmania dan Hasan Almuthahar, Resolusi konflik dan Politik lokal di Kalimantan Barat. Yogyakarta: Bulak Sumurempat, 2014. pp. 61.

[9] Novri Susan, Sosiologi Konflik dan Isu-Isu Konflik Kontemporer. Jakarta: Kencana Prenada Media Group, 2009, pp. 132.

[10] Irwan Abdullah, Ibdnu Mujib, \& M. Iqbal Ahnaf, Agama dan Kearifan Lokal dalam Tantangan Global. Yogyakarta: Pustaka Pelajar, 2008, pp. 7. 